\title{
The Impact of Entrepreneurial Orientation on New Product Creativity, Competitive Advantage and New Product Performance in SMEs: The Moderating Role of Corporate Life Cycle
}

\author{
Ho-Taek Yi ${ }^{1}$, , Fortune Edem Amenuvor ${ }^{2, *}$ and Henry Boateng ${ }^{3}$ \\ 1 Department of Business Administration, Keimyung University, Daegu 42601, Korea; hotaekyi@kmu.ac.kr \\ 2 Department of Emerging Technology Innovation and Management, Hanil University and Presbyterian \\ Theological Seminary, Jeonbuk 55359, Korea \\ 3 Institutional Research Unit, D’Youville College, Buffalo, NY 14201, USA; hboateng85@gmail.com \\ * Correspondence: famenuvor@hanil.ac.kr
}

\section{check for} updates

Citation: Yi, H.-T.; Amenuvor, F.E. Boateng, H. The Impact of Entrepreneurial Orientation on New Product Creativity, Competitive Advantage and New Product Performance in SMEs: The Moderating Role of Corporate Life Cycle. Sustainability 2021, 13, 3586. https://doi.org/10.3390/su13063586

Academic Editor: Mário José Baptista Franco

Received: 20 February 2021

Accepted: 16 March 2021

Published: 23 March 2021

Publisher's Note: MDPI stays neutral with regard to jurisdictional claims in published maps and institutional affiliations.

Copyright: (c) 2021 by the authors. Licensee MDPI, Basel, Switzerland. This article is an open access article distributed under the terms and conditions of the Creative Commons Attribution (CC BY) license (https:/ / creativecommons.org/licenses/by/ $4.0 /)$.

\begin{abstract}
The current study aims to empirically examine the effect of entrepreneurial orientation on new product creativity, competitive advantage, and new product performance. Data are collected from 424 Small and Medium-sized Enterprises (SMEs) in South Korea. The suggested hypotheses are tested through the structural equation modeling technique. The analysis outcome shows that entrepreneurial orientation has a significant positive effect on both new product (NP) novelty and new product meaningfulness. The study further finds that both new product novelty and meaningfulness have significant positive impacts on competitive advantage, respectively, while the latter has a significant positive effect on new product performance. Similarly, the study finds that corporate life cycle significantly moderates the relationship between entrepreneurial orientation and new product meaningfulness. The study offers practical and theoretical insights into understanding entrepreneurship dynamics, new product creativity, and new product performance. The research shows that SME managers must adopt an entrepreneurial orientation at an early stage in the life cycle.
\end{abstract}

Keywords: entrepreneurial orientation; SMEs; new product creativity; new product performance; corporate life cycle; new product innovation

\section{Introduction}

An accumulating body of knowledge has shown that new product development is a vital part of the survival of small and medium-sized enterprises [1-3]. Indeed, Ref. [4] aver that SMEs' lifeblood when competing in highly competitive markets is new product development. This is primarily because small and medium-sized businesses have fewer products than larger corporations and are heavily dependent on new product sales to survive [5]. To succeed in a hyperactive global market, small and medium-sized firms must develop new products that generate long-term growth and prosperity [6]. Research on new product development has also highlighted the value of creativity in maintaining overall performance [7,8], and the role of entrepreneurial orientation [9]. However, considering the significant role of new product development in small and medium-sized enterprises in the extant literature $[10,11]$, it appears that the literature has some primary deficiencies. First, the entrepreneurial orientation (EO) literature seems to have paid limited attention to new product marketing [11-13]. Previous EO research seems to have concentrated primarily on EO's effect on performance, with virtually no study assessing the link between EO and new product creativity. Second, while EO and new product performance are vital factors for small and medium-sized companies [14], the causal relationship between these two variables has not yet been identified. Furthermore, the current EO literature has paid little attention to the competitive advantage of new product development. Researchers have 
argued that the competitive advantage separates rivals and even becomes the trump card within the SME context [15-17]. Finally, it has been argued that the firm's life cycle stage could affect its performance level [18]. However, little is known about this relationship.

The justification in filling these gaps is premised on the fact that the development and performance of new products are crucial for SMEs' survival. However, to a more considerable extent, new product development and performance depend on the strategic orientation of the firms as well as the creativity of the new products. However, because prior research has paid limited attention to these critical causal relationships, the current study is relevant and opportune as it seeks to fill these gaps.

Consequently, in addressing these limitations, we set out to evaluate EO's effect on new product creativity, competitive advantage, and performance empirically while assessing the moderating influence of the corporate life cycle in the SME context. The study aims therefore to empirically examine the effect of entrepreneurial orientation on new product creativity, competitive advantage, and new product performance. We position this research in the SME context because of the need for newer product development and performance in this sector compared to larger firms. Drawing on a resource-based view theory, this current research pushes EO research limits by explicating how EO affects new product creativity, including the novel and meaningful characteristics of new products created during product creation and start-up phases. The study further assesses how these two facets of new product creativity (novelty and meaningfulness) produce competitive advantages that contribute to superior new product performance [19]. Finally, we take a step forward to evaluate the corporate life cycle's moderating role on the nexus between EO and new product creativity. The research asks the following questions: what is the effect of entrepreneurial orientation on both new product novelty and new product meaningfulness? What are the effects of both new product novelty and new product meaningfulness on competitive advantage? What is the effect of competitive advantage on new product performance? What this the moderating effect of corporate life cycle on the relationship between entrepreneurial orientation and new product novelty? What is the moderating effect of corporate life cycle on the relationship between entrepreneurial orientation and new product meaningfulness?

This study makes a modest contribution to knowledge in that, while other studies have tried to analyze factors that affect new product performance, as far as we are aware, this research is the first to show how entrepreneurship, as a strategic orientation of small and medium-sized enterprises, generates new product creativity, competitive advantage, and new product performance. This research further contributes to knowledge by evaluating the role of the corporate life cycle in the above relationship and finds that instilling entrepreneurship in the early stage of the corporate life cycle can go a long way towards optimizing new product creativity and performance. This study underlines the relevant role that strategic orientation plays in developing creative new products and creating competitive advantages that lead to improved performance.

\section{Theoretical Background}

\subsection{The Resource-Based View}

Ref. [20] argues that a resource-based approach begins with a criticism of the theory of industrial organization that stresses on the effect of environmental factors on the industry's output to which the business relates and specifically seeks capabilities and internal resources. In line with the above, Ref. [21] suggests that to benefit from a competitive edge for the company's business resource, it should obtain valuable, rare, inimitable, and nonsubstitutable (VRIN) resources and skills, and the entity in a position which can absorb and enforce them. To maintain a better competitive advantage, the core principle of this theory is that businesses must develop and maintain resources and capabilities. Several analogous analyses determine this recommendation: core competencies, dynamic capabilities, and knowledge-based perspectives [22-24]. The resource-based view has been applied in previous research. For instance, Ref. [18] used it in explaining how SME entrepreneurship 
leads to dynamic capabilities and technical performance. Similarly, Ref. [25] applied it to explicate strategic human resource management, while [26] used it to conceptualize supply chain learning. The resource-based view fits well with EO [27] and is therefore adopted as the theoretical lens since the current study examines how SMEs' EO affects new product creativity and competitive advantage (essential resources) and new product performance.

\subsection{Entrepreneurial Orientation}

Growing evidence shows that EO is essential to the sustainability and creation of enterprises and nations' economic stability [28-30]. EO encapsulates the processes, provisions, procedures, and decision-making styles used by management to behave in an entrepreneurial manner [31-37]. Previous research into entrepreneurship identified entrepreneurship as a multidimensional theory of innovation, proactiveness, and risktaking [38]. Innovation was promoted by [39] to show that entrepreneurs play the most crucial role in economic activities. Second, both the pragmatic propensity towards competition and the forward-looking and goal-oriented behavioral tendency towards business opportunities are referred to as proactiveness [40]. Finally, risk-taking relates to an entrepreneur's imaginative and challenging decision-making ability to capture business opportunities - that is, a willingness to seize market opportunities and boldly confront them with confidence in business success [41] or as an inclination for high-risk business opportunities [42]. Although entrepreneurship refers to new entry, its EO relates to the entrepreneurial process, such as how entrepreneurship is conducted-the strategies, methods, and decision-making strategies used to work in an entrepreneurial manner [43,44]. It is easy to believe that $\mathrm{EO}$ will contribute to new product creativity in light of the preceding discussion, as studies have revealed that creativity is the physical representation of innovation [45].

\subsection{Creativity}

Research on creativity arose from many creativity concepts [46]. In most of the conceptualizations, however, two central elements stand out: the novelty of the solution to a specific problem and the appropriateness and applicability [47-49]. In essence, creativity may be seen as producing novel, useful ideas and solutions to problems [50]. We concentrate on new product creativity in line with the priorities of the current research. The creativity of new products is characterized as the extent to which new products are viewed as reflecting distinctive differences in ways relevant to prospective consumers from the products of competitors [51]. We adopt the "output point of view" of creativity, in line with [52] and [53], which highlights two distinct parameters of creativity: the unique difference, (i.e., the novelty component, conceptualized as the extent to which new products are perceived as representing notable differences from rivals) and the meaningfulness for prospective consumers (i.e., the meaningfulness dimension, highlighted as the degree of perceiving new products as appropriate).

In the conceptualization of creativity, Ref. [52] argues that it is essential to include all aspects of the conceptualization of creativity since the intended audience may see ideas as bizarre or odd if they are novel or have an unusual meaning for the consumer. Therefore, our research conceptualizes two distinct dimensions of creativity in line with [51]: new product novelty and new product meaningfulness.

\subsection{Competitive Advantage}

Competitive advantage refers to an attribute that helps businesses to outperform their rivals [20]. Access to resources or skills may be mainly a competitive advantage [53]. Ref. [54] described two fundamental ways for a company to gain a competitive advantage over its competitor: cost advantage and differentiation advantage. The cost advantage is the company's ability to deliver the same products and services as its competitors but at a lower cost. Furthermore, the differentiation advantage is gained when a company provides better products and services than its rivals. [54] underlines the need for strategic management 
to be concerned with developing an enduring competitive advantage. In the background of this study, and in line with Passemard and Calantone (2000), we argue that small and medium-sized enterprises' ability to deploy new product creativity efficiently will contribute to superior performance by enabling them to outperform existing or potential companies with competitive advantages. Companies' business strategies manipulate the various resources over which they have direct control in order to gain a competitive advantage, and these resources could produce a competitive advantage [55]. In effect, the competitive advantage is demonstrated by superior performance results and dominance in product resources [53]. The competitive advantage can also help to boost the efficiency of new products.

\subsection{New Product Performance}

The development of new products demonstrates the degree to which new products are perceived to have achieved their market share, revenue growth, consumer use, and profit goals [56]. While sometimes referred to as new product success, new products performance has been a necessary consequence of any new product development initiative. Several researchers have identified various operationalizations and measures for new product performance. For example, Ref. [57] operationalizes new product performance using market share, sales growth, and sales goal accomplishment growth rate. While there seems to be no agreement, with some scholars arguing for subjective, interval-scale measures regarding the evaluation of new product performance $[57,58]$, others have used experimental and archival measures $[59,60]$. There seems to be a convergence towards subjective measures amid this apparent blurring and disputes on the subjective-objective evaluation issue, and most research on new product performance tends to indicate that subjective measures have consistently strong associations with new objective performance measures [61,62].

\subsection{Corporate Life Cycle}

The corporate life cycle in the extant literature has been conceptualized differently. Earlier research indicates that this life cycle focuses on five distinct phases (birth, growth, maturity, revival, and decline) [63]. The birth phase, or stage one [64], is when the new firm becomes an organization. An organization competes with industry rivals in the growth stage and knows initial success. The third stage is the maturity period, during which the creative activities of an organization decrease, but its internal activities still operate effectively $[65,66]$. In this process, the profitability of a business is maximized, and cash accumulates. Companies try to diversify their product offerings in the revival phase to succeed in the industry and not lose market share. In some instances, the focus is also on more advanced control and planning systems [67]. Companies (or even whole markets) "dry up" and begin to crash in the final phase-decline. Failure to diversify and complete mergers or acquisitions may result in the withdrawal of business.

Extant research highlights that in the first three phases of the organizational life cycle, entrepreneurship expression is continuously increasing. The disparity in entrepreneurship arises in renewal and decline and is mainly due to innovation and creativity. In the renewal stage, innovation and creativity reach new growth levels, while they are almost abandoned during the decline phase. In its nature, renewal is close to the start-up period when entrepreneurship is prevalent. [67] argue that the business also ventures into new markets and facilitates entrepreneurial activity again by moving to renewal (i.e., it acts innovatively and proactively).

\section{Research Model and Hypothesis}

\subsection{Research Model}

Based on the preceding discussions, our research model is presented in Figure 1. The authors hypothesize that EO positively affects new product creativity, which is divided into NP novelty and NP meaningfulness, as explained in the theoretical background 
(H1 and H2). Second, it is hypothesized that the NP creativity (i.e., NP novelty and NP meaningfulness) will affect the competitive advantage ( $\mathrm{H} 3$ and $\mathrm{H} 4$ ). Third, $\mathrm{H} 5$ hypothesizes that a company's competitive advantage will positively impact NP performance. Finally, H6 is that the firm's corporate life cycle will moderate the relationship between EO and new product creativity.

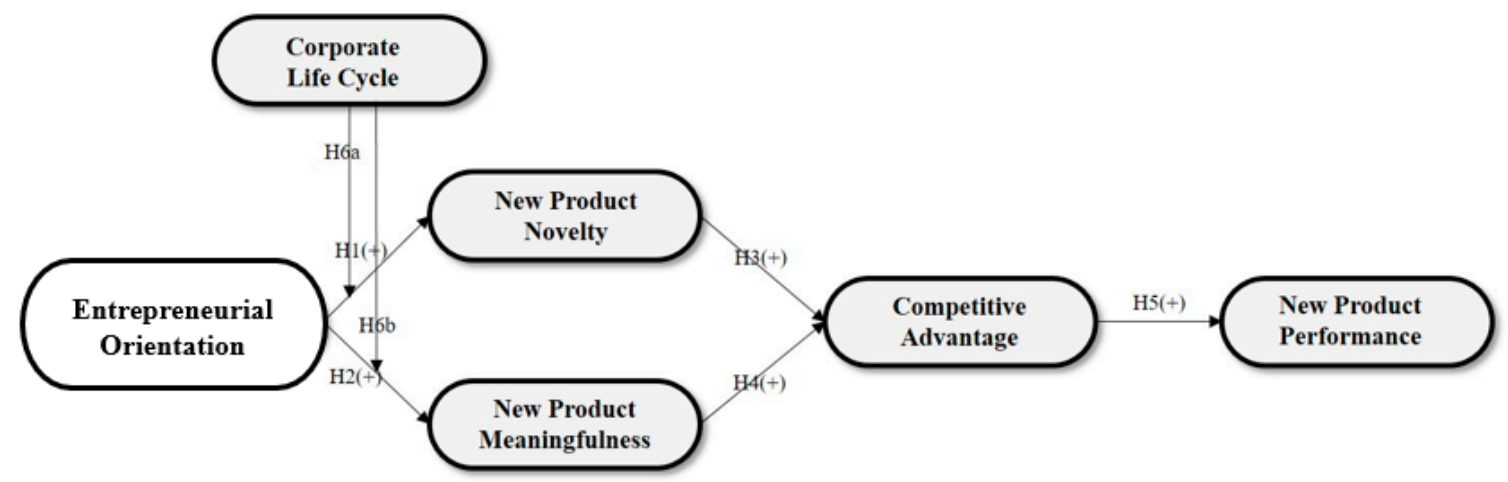

Figure 1. Research model.

\subsection{Hypotheses}

\subsubsection{EO and NP Creativity}

Three key dimensions, such as innovativeness, proactivity, and risk-taking, are components of the EO variable that work together to form a unidimensional "gestalt", as mentioned previously [18,68,69]. Ref. [70] claim that EO is a kind of business culture that drives businesses to introduce new products. They recognize that they act more creatively, intimately, and bravely when companies imbue EO in their work [70]. Although there has been little attention paid to how EO generates new product creativity, this paper argues that the various aspects of EO are catalysts for adopting creativity in new product development. In conceptualizing the relationship between EO and creativity, Ref. [45] noted that creativity, and, for that matter, new product creativity, are EO's ultimate effects. Three streams of convergent literature form a nexus [71] namely new product development, creativity, and EO, offering potential explanations for the success of new product development and creativity for new products. Innovation, which has been argued to be a significant part of EO [8] is conceptualized as an act of cannibalizing creativity [46]. In essence, the adoption of $\mathrm{EO}$ as a strategic orientation within the business is the apparent option for employees to act creatively in new product development ventures. Based on our previous conceptualization of new product creativity as involving both new product novelty and new product meaningfulness, we argue that EO will enhance new product creativity and propose that:

Hypotheses 1 (H1). EO will have a positive impact on NP novelty.

Hypotheses $2 \mathbf{( H 2 ) . ~ E O ~ w i l l ~ h a v e ~ a ~ p o s i t i v e ~ i m p a c t ~ o n ~ N P ~ m e a n i n g f u l n e s s . ~}$

\subsubsection{NP Creativity and Competitive Advantage}

The new product's competitive advantage is one of the most significant determinants of superior new product performance [72,73]. In terms of product differentiation and customer satisfaction, it is defined as a product's perceived dominance over rival goods. The first aspect of the new product advantage, product differentiation, is the extent of distinctiveness in terms of the product image and competitive positioning (e.g., premium brand/price) of the new product relative to competing products $[73,74]$. The second dimension of the new product advantage, consumer satisfaction, is the extent to which the new product exceeds the client's needs and desires [75]. It also reflects the level of customer knowledge of purchasing a new product corresponding to the price paid $[76,77]$. Earlier studies have shown that new product creativity creates new product advantages by 
enhancing its new and useful characteristics [78,79]. New technologies or product designs help to meet unusual consumer requirements more effectively than competitive products, according to [73].

The new product offerings, focused on an advanced technical portfolio, are expected to help achieve a premium position for the new product, distinguishing it from competitors' goods. Hence, we set the following hypothesis:

Hypotheses 3 (H3). NP novelty will have a positive impact on competitive advantage.

Previous research on the new product advantage has shown that new products' creativity can lead to a competitive advantage for the new product by meaningfully satisfying unique/differentiated market demands $[56,80]$. Meaningful new products can also increase products' differentiation by including superior prototypes and unexpected technical innovations to meet customer needs [45]. By adapting and enhancing existing goods and services by quality control and improvement to the current customer's needs, meaningful new products often maximize product-market fit $[81,82]$. To this end, the new product's meaningfulness is expected to increase customer satisfaction for the new product, as it is necessary to fulfill customer needs and wishes. Combining these two points of view means that a company that emphasizes meaningful new product designs gains a competitive advantage by offering unique product features that can provide clear customer benefits and, at the same time, increase customer loyalty. Thus, we propose that:

Hypotheses 4 (H4). NP meaningfulness will have a positive impact on competitive advantage.

\subsubsection{Competitive Advantage and NP Performance}

Products with a more significant competitive advantage have more creative functionality with higher efficiency for customers. All things being equal, these products should provide greater returns to the developing firm for a given amount of product development expenditure. Previous research indicates that a product's competitive advantage provides a concrete picture of a business's ability to meet customer needs. Many studies have found that products' competitive advantage is substantially linked to product success and market performance $[51,56,73,83]$. This connection is subject to further research on market performance, financial performance, and qualitative performance. Some studies have argued that products' competitive advantage consistently seems to be the most important aspect of products in describing the success and performance of new products [84,85]. In terms of choice and preference, we maintain that the competitive advantage of new products puts them ahead of competitors, and this is expressed in the new product's market, financial, and qualitative performance. It is also convenient to argue that the competitive advantage will improve the performance of new products. We, therefore, submit the following hypothesis:

Hypotheses 5 (H5). Competitive advantage will have a positive impact on NP performance.

\subsubsection{Moderating Effect of Corporate Life Cycle between EO and NP Creativity}

Five common stages make up the corporate life cycle: birth, growth, maturity, revival, and decline. Researchers have argued that integral complementarities between environmental policy, structure, and decision-making variables will manifest at each point $[18,67]$. The birth stage, or stage one, is when a new corporation becomes an entity [64]. A company competes with industry rivals at the stage of growth and has experience of initial success. The third stage is the maturity phase, during which the creative activities of the organization decrease, but its internal operations continue to operate efficiently $[65,66]$. The profitability of a company is maximized at this point, and cash accumulates. Companies try to diversify their product offerings at the revival stage to succeed in the industry and not to lose market share. Emphasis is also focused on more complex control and planning systems in some situations [67]. Companies (or even whole markets) dry up at the last stage and start crashing. Failure to diversify and complete mergers or acquisitions can lead to business withdrawals. 
The birth stage, sometimes referred to as the "entrepreneurial stage," is characterized by a great deal of complexity and a period that demands serious risk-taking [67]. The period of growth, also called the "rapid stage of growth," is the phase of the business's expected rapid growth. These two phases are more volatile in this theory than in the other three steps. The authors listed these two phases in this study as the "earlier stages" and the remainder as the "later stages." According to [86], while EO can initially be useful in highly volatile environments, EO's impact is more rapidly reduced when the volatility level is high than when it is low. Therefore, we argue that if an enterprise adopts an EO in response to a variety of environmental conditions, depending on the stage of the business's life cycle, it will have different effects on new product creativity (i.e., new product novelty and new product meaningfulness). EO's impact on NP creativity may be lower than in the later stages, to explain in more detail since the earlier stages are highly volatile. We, therefore, advance the following hypothesis:

Hypotheses 6a (H6a). Corporate life cycle (earlier stages vs. later stages) will have a positive moderating effect between EO and NP novelty.

Hypotheses $\mathbf{6 b} \mathbf{b} \mathbf{H 6 b})$. Corporate life cycle (earlier stages vs. later stages) will have a positive moderating effect between EO and NP meaningfulness.

\section{Methodology}

\subsection{Measurement of Variables}

The items measuring all the constructs were adapted from the extant literature. Items for NP performance have been adapted from [87] and [3], while items for NP novelty and meaningfulness were adapted from [51]. Similarly, items for competitive advantage were adapted from [51]. The EO is a reflective, second-order, three-dimensional collective construct: innovativeness, proactiveness, and risk-taking, calculated with items adapted from [88]. The new product performance is a second-order, three-dimensional, reflective variable (NP market performance; NP financial performance; NP qualitative performance). We used items adapted from [87] and [3] to analyze financial, market, and qualitative performance. A five-point Likert scale anchored on 1 = strongly disagree, 2 = disagree, $3=$ neutral, 4 = agree, and $5=$ strongly agree was used to attenuate ambiguity in the measurement of items.

There is no consensus on the proper approach for classifying corporate life cycle phases concerning the corporate life cycle [89]. Corporate life cycle was analyzed by asking about respondents' perceptions of the company's growth [90]. We used the following stage options to be consistent with our concept of the construct: birth (coded 1), growth (coded 2), maturity (coded 3), and decline (coded 4). Because of the absence of samples, birth and growth were combined to reflect earlier stages, while maturity and decline were combined to represent later stages. We believed firm size as a control variable could potentially impact on NP performance [48]. It was measured using the total number of employees of the firm. See Appendix A for the measurement items.

\subsection{Sampling Design}

In addressing the research problem, we adopted a survey research design. A total of 424 small and medium-sized enterprises in South Korea were sampled for this analysis. Under the South Korean Small and Medium Enterprises Act enacted in 1966, SMEs are defined as firms with less than 300 employees or 8 billion KRW (Korean won) worth of capital [18]. In this study, we used the number of employees as the selection criteria. Thus, only firms with less than 300 employees were considered in this study. A sample frame of 939 SMEs located in the Daegu-Gyeongbuk area was selected with the cooperation of the Keimyung University Small and Medium Business Support Office. The survey was conducted between March 2020 and May 2020 using a specialized research institute. In total, 796 e-mails were successfully sent out to the potential respondents and 228 valid questionnaires were returned. Apart from the online survey, an offline survey was con- 
ducted through professional surveyors belonging to a specialized research company, and responses were retrieved from a total of 440 companies. Eventually, the authors used responses from 424 companies, excluding 16 respondents who gave biased responses. The respondents spanned staff, section chiefs, managers/team leaders, department heads, and executives/directors. The characteristics of the industry of the sampled respondents are shown in Table 1. According to the results, $11.8 \%$ of the SMEs operated in the automotive sector, $10.8 \%$ worked in the household goods industry, $9.4 \%$ operated in the textiles industry, while $8.5 \%$ operated in the food processing industry. The majority $(24.8 \%)$ were between 6 and 10 years old in terms of the average business duration. The majority (39.4\%) of the businesses sampled had 1 to 9 workers, and the majority (42.2\%) were in the maturity stage of the corporate life cycle. Regarding the type of business operation, $42.0 \%$ indicated that they focused on business management, while the majority $(27.6 \%)$ of the respondents were managers or team leaders. Furthermore, most $(61 \%)$ of the respondents had been working in their current companies for less than 5 years, while the majority $(35.6 \%)$ were between 30 and 39 years of age.

Table 1. Responses' characteristics.

\begin{tabular}{|c|c|c|c|c|c|c|c|}
\hline \multicolumn{2}{|c|}{ Classification } & \multirow{3}{*}{$\begin{array}{l}\mathbf{N} \\
85\end{array}$} & \multirow{3}{*}{$\begin{array}{c}\% \\
20.1\end{array}$} & \multicolumn{2}{|c|}{ Classification } & $\mathbf{N}$ & $\%$ \\
\hline \multirow{6}{*}{ Year of Establishment } & \multirow{2}{*}{ Less than 5 years } & & & \multirow{21}{*}{ Industry Sectors } & Health food & 11 & 2.6 \\
\hline & & & & & Education & 6 & 1.4 \\
\hline & 6 to 10 years & 105 & 24.8 & & Metal & 22 & 5.2 \\
\hline & 11 to 20 years & 94 & 22.2 & & Finance & 2 & 0.5 \\
\hline & 21 to 30 years & 74 & 17.5 & & Mechanical equipment & 33 & 7.8 \\
\hline & More than 30 years & 66 & 15.6 & & Robotics & 13 & 3.1 \\
\hline \multirow{4}{*}{ Corporate Life Cycle } & Birth stage & 30 & 7.1 & & Cosmetics & 6 & 1.4 \\
\hline & Growth stage & 170 & 40.1 & & Household goods & 46 & 10.8 \\
\hline & Maturity stage & 179 & 42.2 & & Textiles & 40 & 9.4 \\
\hline & Revival/decline stage & 45 & 10.6 & & Smart factory & 7 & 1.7 \\
\hline \multirow{8}{*}{ Number of Employees } & \multirow{3}{*}{1 to 9 persons } & \multirow{3}{*}{167} & \multirow{3}{*}{39.4} & & Food processing & 36 & 8.5 \\
\hline & & & & & Web development & 20 & 4.7 \\
\hline & & & & & Clothing & 16 & 3.8 \\
\hline & 10 to 29 persons & 115 & 27.1 & & Medicine & 28 & 6.6 \\
\hline & 30 to 49 persons & 41 & 9.7 & & Printing & 8 & 1.9 \\
\hline & 50 to 99 persons & 39 & 9.2 & & Automotive parts & 50 & 11.8 \\
\hline & \multirow[t]{2}{*}{100 to 299 persons } & \multirow[t]{2}{*}{62} & \multirow{2}{*}{14.6} & & Electronics & 34 & 8.0 \\
\hline & & & & & Consulting & 8 & 1.9 \\
\hline \multirow{8}{*}{$\begin{array}{l}\text { Type of business } \\
\text { operation }\end{array}$} & R\&D & 52 & 12.3 & & Real estate & 5 & 1.2 \\
\hline & Business Management & 178 & 42.0 & & Energy & 8 & 1.9 \\
\hline & Marketing & 12 & 2.8 & & Other & 25 & 5.9 \\
\hline & Sales & 73 & 17.2 & \multirow{4}{*}{ Age } & Between 20 and 29 years & 72 & 17.0 \\
\hline & Manufacturing & 48 & 11.3 & & Between 30 and 39 years & 152 & 35.6 \\
\hline & Quality Control & 16 & 3.8 & & Between 40 and 49 years & 138 & 32.5 \\
\hline & Accounting & 11 & 2.6 & & 50 years and above & 62 & 14.6 \\
\hline & Other & 34 & 8.0 & \multirow{5}{*}{$\begin{array}{l}\text { Number of Years in } \\
\text { Current Working } \\
\text { Company }\end{array}$} & & 259 & 61 \\
\hline \multirow{6}{*}{ Work Position } & Staff & 111 & 26.2 & & Less than years & & \\
\hline & Section chief & 64 & 15.1 & & 6 years to years & 89 & 21.0 \\
\hline & Manager/team leader & 117 & 27.6 & & 10 years to 19 years & 66 & 15.6 \\
\hline & Department head & 79 & 18.6 & & More than 20 years & 9 & 2.1 \\
\hline & Executive/director & 43 & 10.1 & \multirow{2}{*}{ Survey Type } & Online Survey & 228 & 53.8 \\
\hline & No response & 10 & 2.4 & & Offline Survey & 196 & 46.2 \\
\hline
\end{tabular}




\subsection{Non-Response Bias and Common Method Bias}

With two approaches, we assessed possible non-response bias. According to [90]'s methods, the authors performed tests to compare early and late respondents' critical study variables. The findings showed that there was no difference between the two groups $(p>0.05)$. Secondly, we compared whether the response values varied between the online survey $(n=228)$ and the offline survey $(n=196)$. In this analysis, no substantial differences $(p>0.05)$ were observed, either. In the current study, data for all the constructs, using a self-report questionnaire, were collected from the same source. There is also a possibility that there may have been a common variance in the process. The authors assessed the potential issue of single-factor analysis for all the items [91]. As expected, from an unrotated factor analysis, six different factors were extracted, accounting for 68.25 percent of the total variance and 36.24 percent of the first. Therefore, there was no single factor, and none of the factors accounted for most of the variance.

\subsection{Reliability and Validity Analysis}

Cronbach's alpha test was performed to evaluate the internal consistency of the variables measured by multiple items. As can be gleaned from Table 2, all variables showed values above the minimum threshold value of 0.7 [92]. To assess the measures' reliability and validity, confirmatory factor analysis (CFA) was also conducted. The outcome of the CFA (Model fit: $\chi^{2}=1197.367$, d.f. $=707, \chi^{2} /$ d.f. $=1.694,(\mathrm{RMR}=0.029$, RMSEA $=0.040, \mathrm{GFI}=0.873, \mathrm{NFI}=0.933, \mathrm{RFI}=0.926, \mathrm{IFI}=0.971, \mathrm{TLI}=0.968, \mathrm{CFI}=0.971)$ revealed an adequate model fit for the proposed measurement model. Note: RMR $=$ Root Mean Square Residual, RMSEA= Root Mean Square Error of Approximation, GFI= Goodness of Fit, NFI= Normed Fit Index, TLI= Tucker Lewis index, RFI= Relative Fit Index, IFI= Incremental Fit Index, CFI= Comparative Fit Index.

Table 2. Result of reliability and validity test.

\begin{tabular}{|c|c|c|c|c|c|c|c|c|}
\hline \multicolumn{2}{|c|}{ Item } & Construct & st. Estimate & S.E. & C.R. & AVE & CR & Cronbach's \\
\hline \multirow{3}{*}{$\begin{array}{c}\text { 2nd } \\
\text { Order } \\
\text { Construct }\end{array}$} & Innovativeness & \multirow{3}{*}{$\begin{array}{l}\text { Entrepreneurial } \\
\text { Orientation }\end{array}$} & 0.835 & - & - & \multirow{3}{*}{0.674} & \multirow{3}{*}{0.917} & \multirow{3}{*}{0.952} \\
\hline & Risk-taking & & 0.727 & 0.089 & 12.330 & & & \\
\hline & Proactiveness & & 0.893 & 0.089 & 13.951 & & & \\
\hline \multirow{3}{*}{$\begin{array}{c}\text { 2nd } \\
\text { Order } \\
\text { Construct }\end{array}$} & $\begin{array}{c}\text { Market } \\
\text { Performance }\end{array}$ & \multirow{3}{*}{ NP Performance } & 0.940 & - & - & \multirow{3}{*}{0.834} & \multirow{3}{*}{0.968} & \multirow{3}{*}{0.959} \\
\hline & $\begin{array}{c}\text { Financial } \\
\text { performance }\end{array}$ & & 0.913 & 0.047 & 20.536 & & & \\
\hline & $\begin{array}{l}\text { Qualitative } \\
\text { Performance }\end{array}$ & & 0.886 & 0.046 & 18.979 & & & \\
\hline \multicolumn{2}{|c|}{ Innovativeness1 } & \multirow{5}{*}{ Innovativeness } & 0.793 & - & - & \multirow{5}{*}{0.715} & \multirow{5}{*}{0.945} & \multirow{5}{*}{0.926} \\
\hline \multicolumn{2}{|c|}{ Innovativeness2 } & & 0.845 & 0.048 & 22.339 & & & \\
\hline \multicolumn{2}{|c|}{ Innovativeness3 } & & 0.870 & 0.057 & 20.382 & & & \\
\hline \multicolumn{2}{|c|}{ Innovativeness4 } & & 0.895 & 0.060 & 21.022 & & & \\
\hline \multicolumn{2}{|c|}{ Innovativeness5 } & & 0.821 & 0.061 & 18.876 & & & \\
\hline \multicolumn{2}{|c|}{ Risktaking1 } & & 0.871 & - & - & \multirow{5}{*}{0.757} & \multirow{5}{*}{0.952} & \multirow{5}{*}{0.941} \\
\hline \multicolumn{2}{|c|}{ Risktaking2 } & & 0.881 & 0.033 & 28.750 & & & \\
\hline \multicolumn{2}{|c|}{ Risktaking3 } & Risk-Taking & 0.918 & 0.039 & 26.037 & & & \\
\hline \multicolumn{2}{|c|}{ Risktaking4 } & & 0.880 & 0.041 & 22.715 & & & \\
\hline \multicolumn{2}{|c|}{ Risktaking5 } & & 0.797 & 0.042 & 20.369 & & & \\
\hline \multicolumn{2}{|c|}{ Proactiveness1 } & & 0.854 & - & - & \multirow{5}{*}{0.747} & \multirow{5}{*}{0.953} & \multirow{5}{*}{0.939} \\
\hline \multicolumn{2}{|c|}{ Proactiveness2 } & & 0.852 & 0.037 & 26.066 & & & \\
\hline \multicolumn{2}{|c|}{ Proactiveness3 } & Proactiveness & 0.901 & 0.040 & 24.802 & & & \\
\hline Pro & eness4 & & 0.861 & 0.045 & 22.700 & & & \\
\hline Pro & eness5 & & 0.852 & 0.042 & 22.308 & & & \\
\hline
\end{tabular}


Table 2. Cont.

\begin{tabular}{|c|c|c|c|c|c|c|c|}
\hline Item & Construct & $\begin{array}{c}\text { st. } \\
\text { Estimate }\end{array}$ & S.E. & C.R. & AVE & CR & $\begin{array}{c}\text { Cronbach's } \\
\alpha\end{array}$ \\
\hline NP_novelty5 & \multirow{5}{*}{ NP Novelty } & 0.892 & - & - & \multirow{5}{*}{0.805} & \multirow{5}{*}{0.959} & \multirow{5}{*}{0.956} \\
\hline NP_novelty4 & & 0.863 & 0.030 & 32.026 & & & \\
\hline NP_novelty3 & & 0.916 & 0.035 & 28.569 & & & \\
\hline NP_novelty2 & & 0.919 & 0.037 & 28.774 & & & \\
\hline NP_novelty1 & & 0.895 & 0.036 & 27.653 & & & \\
\hline NP_meaningfulness1 & \multirow{5}{*}{$\begin{array}{c}\mathrm{NP} \\
\text { Meaningfulness }\end{array}$} & 0.873 & - & - & \multirow{5}{*}{0.776} & \multirow{5}{*}{0.965} & \multirow{5}{*}{0.944} \\
\hline NP_meaningfulness2 & & 0.885 & 0.039 & 25.480 & & & \\
\hline NP_meaningfulness3 & & 0.922 & 0.043 & 24.920 & & & \\
\hline NP_meaningfulness4 & & 0.880 & 0.039 & 25.156 & & & \\
\hline NP_meaningfulness5 & & 0.844 & 0.040 & 23.225 & & & \\
\hline Marketperf1 & \multirow{4}{*}{$\begin{array}{l}\text { NP Market } \\
\text { Performance }\end{array}$} & 0.897 & - & - & \multirow{4}{*}{0.783} & \multirow{4}{*}{0.959} & \multirow{4}{*}{0.935} \\
\hline Marketperf2 & & 0.910 & 0.033 & 29.923 & & & \\
\hline Marketperf3 & & 0.889 & 0.036 & 25.404 & & & \\
\hline Marketperf4 & & 0.841 & 0.042 & 21.219 & & & \\
\hline Financialperf1 & \multirow{3}{*}{$\begin{array}{l}\text { NP Financial } \\
\text { Performance }\end{array}$} & 0.909 & - & - & \multirow{3}{*}{0.831} & \multirow{3}{*}{0.957} & \multirow{3}{*}{0.936} \\
\hline Financialperf2 & & 0.923 & 0.033 & 31.101 & & & \\
\hline Financialperf3 & & 0.902 & 0.035 & 29.397 & & & \\
\hline Qualitativeperf1 & \multirow{3}{*}{$\begin{array}{l}\text { NP Qualitative } \\
\text { Performance }\end{array}$} & 0.880 & - & - & \multirow{3}{*}{0.786} & \multirow{3}{*}{0.949} & \multirow{3}{*}{0.916} \\
\hline Qualitativeperf2 & & 0.893 & 0.040 & 25.820 & & & \\
\hline Qualitativeperf3 & & 0.886 & 0.039 & 25.449 & & & \\
\hline C_advantage1 & \multirow{5}{*}{$\begin{array}{l}\text { Competitive } \\
\text { Advantage }\end{array}$} & 0.761 & - & - & \multirow{5}{*}{0.596} & \multirow{5}{*}{0.921} & \multirow{5}{*}{0.865} \\
\hline C-advantage 2 & & 0.793 & 0.067 & 15.844 & & & \\
\hline C_advantage3 & & 0.766 & 0.065 & 15.330 & & & \\
\hline C_advantage4 & & 0.761 & 0.074 & 13.945 & & & \\
\hline C-advantage5 & & 0.780 & 0.073 & 14.738 & & & \\
\hline
\end{tabular}

Model fit: $\chi^{2}=1197.367$, d.f. $=707, \chi^{2} /$ d.f. $=1.694, \mathrm{RMR}=0.029, \mathrm{RMSEA}=0.040, \mathrm{GFI}=0.873, \mathrm{NFI}=0.933, \mathrm{RFI}=0.926, \mathrm{IFI}=0.971$, TLI $=0.968$, CFI $=0.971$.

In assessing the reliability of the measures, Ref. [93] highlighted the need to check construct reliability (CR) and average variance extracted (AVE). Ref. [94] define two parameters for measuring reliability: each measurement scale's estimated value must be 0.60 or more, and the AVE must be 0.5 or more. The requirements for CR and AVE were met, as reported in Table 2. This is because the multiple-items scale exceeded the recommended cut-off points of 0.6 and 0.50 , respectively.

To check the discriminant validity, we examined the relationships between the variables and performed a correlation analysis before testing the hypotheses. As can be viewed from Table 3, correlations were found to be consistent with the overall hypotheses between variables deduced from the hypotheses, whereas the fraction's AVE value was greater than the correlation value square in all constructs [93]. 
Table 3. Result of correlation analysis matrix.

\begin{tabular}{|c|c|c|c|c|c|c|c|c|}
\hline Construct & Mean & St. d & (1) & (2) & (3) & (4) & (5) & (6) \\
\hline $\begin{array}{c}\text { Entrepreneurial } \\
\text { Orientation } \\
(1)\end{array}$ & 3.380 & 0.670 & 1 & $0.619^{* *}$ & $0.584^{* *}$ & $0.577^{* *}$ & $0.527^{* *}$ & $-0.099 *$ \\
\hline $\begin{array}{l}\text { New Product } \\
\text { Novelty } \\
(2)\end{array}$ & 3.181 & 0.867 & & 1 & $0.665^{* *}$ & $0.620 * *$ & $0.541^{* *}$ & $-0.199^{* *}$ \\
\hline $\begin{array}{l}\text { New Product } \\
\text { Meaningfulness } \\
\text { (3) }\end{array}$ & 3.612 & 0.722 & & & 1 & $0.672 * *$ & $0.576^{* *}$ & $-0.117^{*}$ \\
\hline $\begin{array}{c}\text { Competitive } \\
\text { Advantage } \\
(4)\end{array}$ & 3.546 & 0.645 & & & & 1 & $0.574^{* *}$ & -0.077 \\
\hline $\begin{array}{l}\text { New Product } \\
\text { Performance } \\
\text { (5) }\end{array}$ & 3.249 & 0.674 & & & & & 1 & $-0.107^{*}$ \\
\hline $\begin{array}{l}\text { Firm Size } \\
(6)\end{array}$ & 4.130 & 1.694 & & & & & & 1 \\
\hline
\end{tabular}

** $p<0.01 ; * p<0.05$. St. $d=$ Standard Deviation

\subsection{Hypotheses Testing}

We analyzed the results using version 26.0 of AMOS. A structural equation modeling technique [95] was then used to evaluate the hypothesized structural model in connection with the sample data obtained. One parameter estimate for each latent variable for the observed items was limited to a value of 1 to facilitate the analysis [96] To expedite analysis, a maximum-likelihood estimation was modeled. Since NP novelty and NP meaningfulness compose NP creativity, the authors set the covariance between these two variables. The final model version and its standardized path coefficient estimates are displayed in Table 4. Statistical significance is demonstrated by each of the paths $(p<0.01$, two-tailed test). The model fit indices for the structural model provide evidence of a good model fit $\left(\chi^{2}=1365.315\right.$, d.f. $=747, \chi^{2} /$ d.f. $=1.828, \mathrm{RMR}=0.054$, RMSEA $=0.044, \mathrm{GFI}=0.862$, $\mathrm{NFI}=0.924, \mathrm{RFI}=0.917, \mathrm{IFI}=0.964, \mathrm{TLI}=0.960, \mathrm{CFI}=0.964)$, in line with [97]. O was significantly related to both new product novelty $(\beta=0.730, t=12.538, p<0.01)$ and new product meaningfulness $(\beta=0.719, t=12.134, p<0.01)$, respectively offering support for $\mathrm{H} 1$ and $\mathrm{H} 2$. In support of $\mathrm{H} 3$ and $\mathrm{H} 4$, the study results show that new product novelty $(\beta=0.352, t=7.193, p<0.01)$ and new product meaningfulness $(\beta=0.532, t=10.152$, $p<0.01)$ are both positively related to competitive advantage. Similarly, the study finds a significant positive relationship between competitive advantage and new product performance $(\beta=0.660, t=11.873, p<0.01)$ in support of H5. From the findings, hypotheses H1 to $\mathrm{H} 5$ were supported.

In order to assess the relevance of effects which are absent in our research model, the authors expanded the CFA model in Table 2 by including firm size as an extra factor with just one indicator and zero error variance. As a result of comparing this expanded CFA model with Table 4 , there was no significant difference except for the chi-square value. 
Table 4. Result of hypothesis test.

\begin{tabular}{|c|c|c|c|c|c|}
\hline Hypothesis & Path & st. Estimate & S.E. & C.R. & Result \\
\hline $\mathrm{H} 1(+)$ & $\begin{array}{c}\text { Entrepreneurial Orientation } \rightarrow \text { NP } \\
\text { Novelty }\end{array}$ & $0.730 * *$ & 0.093 & 12.538 & Supported \\
\hline $\mathrm{H} 2(+)$ & $\begin{array}{c}\text { Entrepreneurial Orientation } \rightarrow \text { NP } \\
\text { Meaningfulness }\end{array}$ & $0.719^{* *}$ & 0.079 & 12.134 & Supported \\
\hline $\mathrm{H} 3(+)$ & NP Novelty $\rightarrow$ Competitive Advantage & $0.352 * *$ & 0.034 & 7.193 & Supported \\
\hline $\mathrm{H} 4(+)$ & $\begin{array}{c}\text { NP Meaningfulness } \rightarrow \text { Competitive } \\
\text { Advantage }\end{array}$ & $0.532 * *$ & 0.044 & 10.152 & Supported \\
\hline $\mathrm{H} 5(+)$ & $\begin{array}{c}\text { Competitive Advantage } \rightarrow \mathrm{NP} \\
\text { Performance }\end{array}$ & $0.660 * *$ & 0.064 & 11.873 & Supported \\
\hline
\end{tabular}

** $p<0.01$. Model fit: $\chi^{2}=1365.315$, d.f. $=747, \chi^{2} /$ d.f. $=1.828$, RMR $=0.054$, RMSEA $=0.044$, GFI $=0.862$, NFI $=0.924$, RFI $=0.917$, IFI $=$ $0.964, \mathrm{TLI}=0.960, \mathrm{CFI}=0.964$.

A multi-group analysis was used to test Hypothesis 6 ( $a$ and $b$ ) to examine the corporate life cycle's moderating effect on the relationship between entrepreneurial orientation and the novelty and meaningfulness of new products, respectively. The multi-group analysis is the most used technique to test the differences between groups. To guarantee homogeneity and inter-group heterogeneity in the group, the moderating variables were split into two groups, and the difference between the groups was evaluated [98]. We measured the corporate life cycle in four stages (birth, growth, maturity, and revival/decline phase). Therefore, it was possible to evaluate the multi-group difference by dividing it into four groups, but since the number of samples in both groups (birth and revival/decline stage) was relatively small, to analyze the moderating effect, we divided the corporate life cycle into two groups (i.e., earlier stages vs. later stages).

To test the moderating effects of corporate lifecycle (CLC) stages in the SEM model, the multi-group analysis approach comparing earlier stages and later stages was used. To test the invariance of the model parameters across the CLC stages, nested comparisons of the constrained model were performed. Table 5 presents the results of model comparisons by $\chi^{2}$ differences. A comparison between unconstrained model (model 1) and measurement weight (model 2) showed a non-significant $\chi^{2}$ difference $(p=0.765)$, supporting the invariance of these parameters across two stages. Subsequently, the constrained model (model 3), in which all structural weights were constrained, was compared with model 2. The addition of constraints on structural paths led to a significant $\chi^{2}$ difference $(p=0.047)$, suggesting that at least one of the structural weights varies across stages.

Table 5. Invariance test.

\begin{tabular}{ccccccc}
\hline Model & $\chi^{2}$ & d.f. & CFI & RMSEA & $\Delta \chi^{2}$ (d.f.) & $p$-Value \\
\hline $\begin{array}{c}\text { Model 1. } \\
\text { Unconstrained model }\end{array}$ & 2307.884 & 1494 & 0.795 & 0.036 & - \\
\hline $\begin{array}{c}\text { Model 2. } \\
\text { Measurement weights }\end{array}$ & 2332.923 & 1525 & 0.793 & 0.036 & $25.039(31)$ & 0.765 \\
\hline $\begin{array}{c}\text { Model 3. } \\
\text { Constrained model }\end{array}$ & 2356.815 & 1539 & 0.792 & 0.036 & $23.892^{*}(14)$ & 0.047 \\
\hline
\end{tabular}

As shown in Table 6, entrepreneurial orientation had a significant positive effect on the NP novelty for later stages $(\beta=-0.772, t=-9.472)$ as well as earlier stages $(\beta=-0.686$, $t=7.991)$. Moreover, entrepreneurial orientation had a significant positive effect on the NP meaningfulness for both earlier stages $(\beta=-0.667, t=7.616)$ and later stages $(\beta=-0.778$, $t=9.299$ ). However, critical ratios for parameter differences confirmed that only one path significantly differed across CLC. The results of the comparison of structural relationships across CLC are presented in Table 6. Therefore, H6b is supported but not H6a. 
Table 6. Result of moderating effect test.

\begin{tabular}{|c|c|c|c|c|c|c|}
\hline \multirow{2}{*}{ Hypothesis } & \multirow{2}{*}{ Path } & \multicolumn{2}{|c|}{ Earlier Stage $(n=200)$} & \multicolumn{2}{|c|}{ Later Stages $(n=224)$} & \multirow{2}{*}{ C.R. } \\
\hline & & $\beta$ & $t$-Value & B & $t$-Value & \\
\hline H6a & Entrepreneurial Orientation $\rightarrow$ NP Novelty & $0.686^{* *}$ & 7.991 & $0.772^{* *}$ & 9.472 & 1.567 \\
\hline $\mathrm{H} 6 \mathrm{~b}$ & $\begin{array}{c}\text { Entrepreneurial Orientation } \rightarrow \mathrm{NP} \\
\text { Meaningfulness }\end{array}$ & $0.667^{* *}$ & 7.616 & $0.778^{* *}$ & 9.299 & $2.435^{* *}$ \\
\hline
\end{tabular}

${ }^{* *} p<0.01$. Earlier stages $=$ birth, growth stage; Later stages $=$ maturity, revival $/$ decline stage.

In addition, the authors investigated the results regarding the roles of the control variable with independent and dependent variables. Firm size had no significant effect on either independent or dependent variables, except NP novelty $(\beta=-0.127, t=-3.350$, $p<0.01$ ). Table 7 presents the final outcomes of the various hypotheses proposed in this study.

Table 7. Status of hypotheses.

\begin{tabular}{lc}
\hline \multicolumn{1}{c}{ Hypothesis } & Status \\
\hline H1: EO will have a positive impact on NP novelty. & supported \\
\hline $\begin{array}{l}\text { H2: EO will have a positive impact on NP } \\
\text { meaningfulness. }\end{array}$ & supported \\
\hline $\begin{array}{l}\text { H3: NP novelty will have a positive impact on } \\
\text { competitive advantage. }\end{array}$ & supported \\
\hline $\begin{array}{l}\text { H4: NP meaningfulness will have a positive impact on } \\
\text { competitive advantage. }\end{array}$ & supported \\
\hline $\begin{array}{l}\text { H5: Competitive advantage will have a positive impact } \\
\text { on NP performance. }\end{array}$ & supported \\
\hline $\begin{array}{l}\text { H6a: Corporate life cycle (earlier stages vs. later stages) } \\
\text { will have a positive moderating effect between EO and } \\
\text { NP novelty. }\end{array}$ & not supported \\
\hline $\begin{array}{l}\text { H6b: Corporate life cycle (earlier stages vs. later stages) } \\
\text { will have a positive moderating effect between EO and } \\
\text { NP meaningfulness. }\end{array}$ & supported \\
\hline
\end{tabular}

\section{Summary of Findings}

\subsection{General Discussion}

The current study's main objective was to better understand SMEs' entrepreneurial orientation and how new product creativity, competitive advantage, and new product performance are generated while considering the corporate life cycle role. These relationships were assessed based on the resource-based theory. Typically, the research found that EO has a significant positive relationship with new product novelty and new product meaningfulness. This result supports [99]'s position that the pursuit of creativity by entrepreneurs leads to product improvement or to more successful manufacturing processes that lead to more effective management. This outcome also highlights [100]'s stance that entrepreneurially focused organizations encourage the creative skills of their workers that are expressed in their new product creativity. In effect, for SMEs to enhance new products' creativity in both novelty and meaningfulness, they must be entrepreneurially oriented by encouraging proactiveness, risk-taking, and innovativeness.

Similarly, the findings reveal a significant positive relationship between new products' creativity (novelty and meaningfulness) and competitive advantage. This finding confirms the view held by [6] that the originality and meaningfulness of new products play major intermediate roles in determining the competitive advantage of products. This finding also lends credence to the position that an organization's ability to acquire creative ideas as intangible assets improves the competitive advantage of its products by providing 
consumers with superior value and by creating core competencies that produce exciting, unexpected products and programs [81]. His implies that SMEs should enhance the creative novelty and meaningfulness of new products to outcompete rivals.

Our study shows that competitive advantage drives new product performance in SMEs; in tandem with [51]'s claim, competitive advantage is significantly correlated with product success and market performance. In terms of choice and preference, new products' competitive advantage puts them ahead of rivals, which is reflected in the new product's market, financial, and qualitative performance.

The moderating influence of the corporate life cycle on the relationship between $\mathrm{EO}$ and the novelty of new products was also explored. Unfortunately, this hypothesis was not supported by the data. This finding, while unexpected, may be attributable to variations in the research context. However, the findings support our hypothesis that the relationship between $\mathrm{EO}$ and new product meaningfulness is moderated by the corporate life cycle. This result reinforces the fact that promoting product creativity can improve new product performance in the early corporate life cycle, which runs in parallel with [18]. In general, the current study advances knowledge by providing empirical insights into a critical aspect of SME marketing management that has received limited attention: what role does EO play in engendering new product creativity, competitive advantage, and new product performance, and what role does corporate life cycle play in the preceding nexus? This study shows, among other things, that when SMEs adopt EO as their strategic orientation, they will develop new product creativity, which will enhance their competitive advantage and, eventually, new product performance. The study further finds that the firm's corporate life cycle moderates the relationship between the firm's EO and new product meaningfulness significantly. From a contextual viewpoint, our research augments existing entrepreneurship research from an Asian perspective [101-103].

\subsection{Theoretical Implications}

This research progresses theory by applying the resource-based view theory to two essential concepts: new product creativity and performance. The study extends the resourcebased view by finding that a firm's EO is a sine qua non to its new product creativity, which is seen as a critical resource (from the resource-based view perspective) for the firm that becomes its competitive advantage and leads to enhancing its performance. This study modestly adds to existing knowledge by providing empirical evidence from a new product creativity and performance perspective to this highly relevant concept with a research framework that exhibits strong explanatory power. The existing EO literature also shows a lack of studies that integrate and analyze the relationship between the concepts used in this study. In previous research, the relationships between these constructs have been evaluated either in isolation or in different formats (see, for instance, Refs. [18,43,44,48], which has led to the need for further empirical review, confirmation, and theoretical advancement. This research further contributes to knowledge by presenting results that evaluate a range of linkages between the constructs used and using data from South Korean SMEs.

\subsection{Managerial Implications}

Small and medium-sized entrepreneurs need to obtain deeper insights into how EO as a business orientation can affect their new product creativity and performance. Key outcomes of the current research can be assessed from these significant viewpoints: that EO increases both new product novelty and meaningfulness; that both new product novelty and meaningfulness increase competitive advantage; that competitive advantage improves new product performance; that corporate life cycle does not moderate the relationship between EO and new product novelty; that corporate life cycle moderates the relationship between $\mathrm{EO}$ and new product meaningfulness.

Therefore, SME managers need to adopt EO as their strategic orientation and engage in more entrepreneurial decision-making to promote new product creativity. Managers will achieve this by encouraging risk-taking, innovativeness, and business proactiveness, which, 
as this research demonstrates, enhances the novelty and meaningfulness of new product creativity. This outcome reflects the relevant role that an organization's strategic orientation plays in the development of creative new products and the creation of competitive advantages. Similarly, to improve the competitive edge and performance of new products, SME managers should concentrate on creating new product novelties by emphasizing the enhancement of the product's novel and useful qualities, as well as the use of advanced technology and product designs to help resolve unique market requirements more competently than competing products. If tactically deployed, novel new product offerings based on sophisticated technology are expected to help achieve a premium position for the new product, differentiate it from existing products, and improve the competitive advantage.

SME managers can also improve the competitive advantage and performance of new products by enhancing the meaningfulness of new products by including superior designs and unexpected technological developments in response to customer needs and preferences. By adapting and improving existing products and services to current market needs and through quality control and enhancements, managers can also increase new products' meaningfulness. Finally, the fact that the corporate life cycle moderates the relationship between $\mathrm{EO}$ and the meaningfulness of new products indicates that the stage in the company's life cycle will affect the rate at which their EO influences their new product creativity. Therefore, it implies that in the earlier stages of the corporate life cycle, instilling entrepreneurship will go a long way towards optimizing the creativity and performance of the new product.

\subsection{Limitations and Future Research}

Considering the constraints below, the findings of the current research must be interpreted carefully. First, our research is confined to small and medium-sized enterprises in South Korea, and thus, the results fall within this scope only. In generalizing this to other contexts, managers and researchers should exhibit caution. Furthermore, the insignificant moderating effect of corporate lifecycle on the link between EO and new product novelty advantage may be due to contextual differences and should, therefore, be tested in other contexts. Similarly, because the concepts discussed in this research could be applicable in different contexts, future studies should also evaluate this model in other contexts. Furthermore, the authors used only 424 SMEs, and, considering the broad nature of the analysis, future research could broaden the sample size to improve generalizability. Interesting findings may be exposed by a subsequent investigation that takes various antecedents and outcomes of new product creativity, such as autonomy and product attractiveness, and adds a different moderating variable, such as competitive intensity.

Author Contributions: Conceptualization, H.-T.Y.; methodology, H.-T.Y.; software, H.-T.Y.; validation, H.-T.Y.; formal analysis, H.-T.Y.; investigation, H.-T.Y. and F.E.A.; resources, H.-T.Y.; data curation, H.-T.Y.; writing — original draft preparation, F.E.A.; writing — review and editing, F.E.A., H.-T.Y., H.B.; visualization, H.-T.Y., and F.E.A.; supervision, H.-T.Y. and H.B.; project administration, H.-T.Y., and F.E.A.; funding acquisition, H.-T.Y. All authors have read and agreed to the published version of the manuscript.

Funding: This research received no external funding.

Institutional Review Board Statement: Not applicable.

Informed Consent Statement: Not applicable.

Data Availability Statement: Data available on request due to ethical and privacy restrictions. The data presented in this study are available on request from the corresponding author. The data are not publicly available due to its classified nature.

Conflicts of Interest: The authors declare no conflict of interest. 


\section{Appendix A. Measurement Items}

\section{A. Entrepreneurship (adopted from Covin \& Slevin 1989)}

\section{Innovativeness (five-point, five-item scale)}

a. In general, the top managers of my firm favor a strong emphasis on $R \& D$, technological leadership and innovation.

b. Top managers place a strong emphasis on tried \& tested practices, equipment, \& products or services.

c. My firm makes many new lines of products or services since the past 5 years.

d. Changes in product or service lines have usually been quite dramatic.

e. We actively introduce improvements and innovations in our business.

\section{Risk-taking (five-point, five-item scale)}

a. In general, the top managers of my firm have a strong proclivity for high-risk projects (with changes of very high returns)

b. In general, the top managers of my firm believe that owing to the nature of the environment, bold, wide-ranging acts are necessary to achieve the firm's objectives

c. When confronted with decision-making situations involving uncertainty, my firm typically adopts a bold, aggressive posture in order to maximize the probability of exploiting potential opportunities.

d. Top managers of my firm emphasizes both exploration and experimentation for opportunities.

e. $\quad$ People in my firm are encouraged to take calculated risks with new ideas.

\section{Proactiveness (five-point, five-item scale)}

a. In dealing with its competitors, my firm typically initiates actions to which competitors then respond.

b. In dealing with its competitors, my firm is very often the first business to introduce new products/services, administrative techniques, operating technologies, etc.

c. In dealing with its competitors, my firm typically adopts a very competitive "undothe -competitors" posture.

d. We always try to take the initiative in every situation (e.g., against competitors, in projects and when working with others)

e. We initiate actions to which other organizations respond

B. New Product Creativity (adapted from Im E Workman 2004)

New Product Novelty (five-point, five-item scale)

Compared to your competitors, the new product you selected

a. $\quad$ is really "out of the ordinary."

b. can be considered as revolutionary

c. is stimulating

d. provides radical differences from industry norms

e. shows an unconventional way of solving problems.

New Product Meaningfulness (five-point, five-item scale)

Compared to your competitors, the new product you selected
a. is relevant to customer's needs
b. is satisfying customer's expectations
c. is considered suitable for customers' desires.
d. is appropriate for customers' needs and expectations
e. is useful for customers.
C. Product competitive advantage (adapted from Im et al. 2013)

Compared with other competing products in the market, our new product...

a. is highly cost effective. 


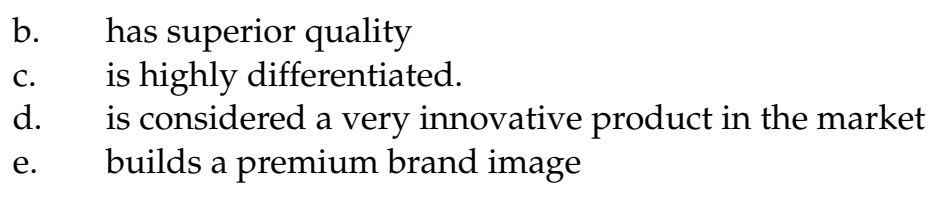

D. New Product Performance (adapted from Griffin \& Page, 1996; Hong et al. 2013)

\section{NP Market Performance}

Relative to your firm's other new products, this product is very successful in terms of
a. sales
b. market share

Relative to competing product in the market, this product is very successful in terms of

c. sales

d. market share

\section{NP Financial Performance}

a. Our new products are successful in terms of ROI

b. Our new products are more successful than competitors' products in terms of ROI

c. Our new products are very successful in terms of ROI compared to our other products.

\section{NP Qualitative Performance}

Relative to your firm's original objectives for this product, this product is very successful in terms of ...
a. customer satisfaction
b. technological advancement
c. overall performances
E. Corporate Life Cycle (adapted from Lumpkin \& Dess 1995)

A firm moves through various phases during its evolution. Please choose the phase which best describes your company. Please choose only one description.

- $\quad$ Birth: The primary focus of our activities is on product developing and design securing adequate financial resources and developing the market, based on meet a need in the market place.

- Growth: Our company is characterized by high growth rates in sales. The major internal focus is around issues of how to produce, sell, and distribute the products in volume.

- Maturity/Diversification: The major internal activities include diversification efforts. We develop second or third generation products or totally new product lines and work on the penetration of new geographic markets.

- Decline: Our company's activities are gradually shrinking, and sales are showing stagnation or decline

\section{F. Control Variables Size (adopted from Blauth et al. 2014)}

\section{Firm Size}

How many people, full-time and part-time, does your business currently employ?

\section{References}

1. Wu, L.; Liu, H.; Su, K. Exploring the dual effect of effectuation on new product development speed and quality. J. Bus. Res. 2020, 106, 82-93. [CrossRef]

2. Zhu, X.; Xiao, Z.; Dong, M.C.; Gu, J. The fit between firms' open innovation and business model for new product development speed: A contingent perspective. Technovation 2019, 86, 75-85. [CrossRef]

3. Hong, J.; Song, T.H.; Yoo, S. Paths to success: How do market orientation and entrepreneurship orientation produce new product success? J. Prod. Innov. Manag. 2013, 30, 44-55. [CrossRef] 
4. Kim, N.; Im, S.; Slater, S.F. Impact of knowledge type and strategic orientation on new product creativity and advantage in high-technology firms. J. Prod. Innov. Manag. 2013, 30, 136-1532. [CrossRef]

5. Cooper, R.G. The drivers of success in new-product development. Ind. Mark. Manag. 2019, 76, 36-47. [CrossRef]

6. Im, S.; Montoya, M.M.; Workman, J.P., Jr. Antecedents and consequences of creativity in product innovation teams. J. Prod. Innov. Manag. 2013, 30, 170-185.2. [CrossRef]

7. Shane, S.A.; Ulrich, K.T. 50th-anniversary article: Technological innovation, product development, and entrepreneurship in management science. Manag. Sci. 2004, 50, 133-144. [CrossRef]

8. Zhang, J.A.; O'Kane, C.; Chen, G. Business ties, political ties, and innovation performance in Chinese industrial firms: The role of entrepreneurial orientation and environmental dynamism. J. Bus. Res. 2020, 121, 254-267. [CrossRef]

9. Morgan, T.; Obal, M.; Anokhin, S. Customer participation and new product performance: Towards the understanding of the mechanisms and key contingencies. Res. Policy 2018, 47, 498-510. [CrossRef]

10. Chang, W.; Taylor, S.A. The effectiveness of customer participation in new product development: A meta-analysis. J. Mark. 2016, 80, 47-64.2. [CrossRef]

11. Drobyazko, S.; Hryhoruk, I.; Pavlova, H.; Volchanska, L.; Sergiychuk, S. Entrepreneurship innovation model for telecommunications enterprises. J. Entrep. Educ. 2019, 22, 1-6.

12. Kraus, S.; Kallmuenzer, A.; Stieger, D.; Peters, M.; Calabrò, A. Entrepreneurial paths to family firm performance. J. Bus. Res. 2018, 88, 382-387. [CrossRef]

13. Malecki, E.J. Entrepreneurship and entrepreneurial ecosystems. Geogr. Compass 2018, 12, e12359.

14. Choo, S.; Woo, H. Causality between entrepreneurial orientation and Business Performance: Conditional Indirect Effect of New Product Development and Organizational Size. Asia-Pac. J. Bus. Ventur. Entrep. 2020, 15, 133-144.

15. Lestari, S.D.; Leon, F.M.; Widyastuti, S.; Brabo, N.A.; Putra, A.H.P.K. Antecedents and consequences of innovation and business strategy on performance and competitive advantage of SMEs. J. Asian Financ. Econ. Bus. 2020, 7, 365-378. [CrossRef]

16. Pratono, A.H.; Darmasetiawan, N.K.; Yudiarso, A.; Jeong, B.G. Achieving sustainable competitive advantage through green entrepreneurial orientation and market orientation. Bottom Line 2019, 32, 2-15. [CrossRef]

17. Quaye, D.; Mensah, I. Marketing innovation and sustainable competitive advantage of manufacturing SMEs in Ghana. Manag. Decis. 2019, 57, 1535-1553. [CrossRef]

18. Yi, H.T.; Han, C.N.; Cha, Y.B. The Effect of Entrepreneurship of SMEs on Corporate Capabilities, Dynamic Capability, and Technical Performances in South Korea. J. Asian Financ. Econ. Bus. 2018, 5, 135-147. [CrossRef]

19. Anderson, E.W.; Mittal, V. Strengthening the satisfaction-profit chain. J. Serv. Res. 2000, 3, 107-120. [CrossRef]

20. Barney, J. Firm resources and sustained competitive advantage. J. Manag. 1991, 17, 99-120. [CrossRef]

21. Barney, J. Gaining and Sustaining Competitive Advantage; Addison-Wesley: Reading, MA, USA, 1997.

22. Hamel, G.; Prahalad, C.K. Competing for the future. Harv. Bus. Rev. 1994, 72, 122-128.

23. Teece, D.J.; Pisano, G.; Shuen, A. Dynamic capabilities and strategic management. Strateg. Manag. J. 1997, 18, 509-533. [CrossRef]

24. Grant, R.M. Toward a knowledge-based theory of the firm. Strateg. Manag. J. 1996, 17, 109-122. [CrossRef]

25. Collins, C.J. Expanding the resource-based view model of strategic human resource management. Int. J. Hum. Resour. Manag. 2020, 32, 331-358. [CrossRef]

26. Yang, Y.; Jia, F.; Xu, Z. Towards an integrated conceptual model of supply chain learning: An extended resource-based view. Supply Chain Manag. An Int. J. 2019, 24, 26. [CrossRef]

27. Adomako, S. Resource-induced coping heuristics and entrepreneurial orientation in dynamic environments. J. Bus. Res. 2020, 122, 477-487. [CrossRef]

28. Covin, J.G.; Wales, W.J. Crafting high-impact Entrepreneurial orientation research: Some suggested guidelines. Entrep. Theory Pract. 2019, 43, 3-18. [CrossRef]

29. Głodowska, A.; Maciejewski, M.; Wach, K. How Entrepreneurial Orientation Stimulates Different Types of Knowledge in the Internationalisation Process of Firms from Poland? Entrep. Bus. Econ. Rev. 2019, 7, 61-73. [CrossRef]

30. Boso, N.; Oghazi, P.; Hultman, M. International entrepreneurial orientation and regional expansion. Entrep. Reg. Dev. 2017, 29, 4-26. [CrossRef]

31. Hunt, R.A. Entrepreneurial orientation and the fate of corporate acquisitions. J. Bus. Res. 2021, 122, 241-255. [CrossRef]

32. Basco, R.; Hernández-Perlines, F.; Rodríguez-García, M. The effect of entrepreneurial orientation on firm performance: A multigroup analysis comparing China, Mexico, and Spain. J. Bus. Res. 2020, 113, 409-421.

33. Calic, G.; Shevchenko, A. How signal intensity of behavioral orientations affects crowdfunding performance: The role of entrepreneurial orientation in crowdfunding business ventures. J. Bus. Res. 2020, 115, 204-220. [CrossRef]

34. Wales, W.J.; Kraus, S.; Filser, M.; Stöckmann, C.; Covin, J.G. The status quo of research on entrepreneurial orientation: Conversational landmarks and theoretical scaffolding. J. Bus. Res. 2020. [CrossRef]

35. Sahaym, A.; Datta, A.A.; Brooks, S. Crowdfunding success through social media: Going beyond entrepreneurial orientation in the context of small and medium-sized enterprises. J. Bus. Res. 2019. [CrossRef]

36. Wach, K.; Głodowska, A.; Maciejewski, M. Entrepreneurial orientation, knowledge utilization and internationalization of firms. Sustainability 2018, 10, 4711. [CrossRef]

37. Lumpkin, G.T.; Dess, G.G. Simplicity as a strategy-making process: The effects of stage or organizational development and environment on performance. Acad. Manag. J. 1995, 38, 1385-1407. 
38. Covin, J.G.; Lumpkin, G.T. Entrepreneurial orientation theory and research: Reflections on a needed construct. Entrep. Theory Pract. 2011, 35, 855-872. [CrossRef]

39. Schumpeter, J.A. History of Economic Analysis; Allen \& Unwin: London, UK, 1954.

40. Lyon, D.W.; Lumpkin, G.T.; Dess, G.G. Enhancing entrepreneurial orientation research: Operationalizing and measuring a key strategic decision-making process. J. Manag. 2000, 26, 1055-1085. [CrossRef]

41. Dess, G.G.; Ireland, R.D.; Zahra, S.A.; Floyd, S.W.; Janney, J.J.; Lane, P.J. Emerging issues in corporate entrepreneurship. J. Manag. 2003, 29, 351-378.

42. Murphy, P.J.; Kickul, J.; Barbosa, S.D.; Titus, L. Expert capital and perceived legitimacy: Female-run entrepreneurial venture signalling and performance. Int. J. Entrep. Innov. 2007, 8, 127-138. [CrossRef]

43. Donbesuur, F.; Boso, N.; Hultman, M. The effect of entrepreneurial orientation on new venture performance: Contingency roles of entrepreneurial actions. J. Bus. Res. 2020, 118, 150-161. [CrossRef]

44. Lee, S.M.; Peterson, S.J. Culture, entrepreneurial orientation, and global competitiveness. J. World Bus. 2000, 35, 401-416. [CrossRef]

45. Peters, M.; Frehse, J.; Buhalis, D. The importance of lifestyle entrepreneurship: A conceptual study of the tourism industry. PASOS. Rev. Tur. Patrim. Cult. 2009, 7, 393-405. [CrossRef]

46. Fillis, I.; Rentschler, R. The role of creativity in entrepreneurship. J. Enterprising Cult. 2010, 18, 49-81. [CrossRef]

47. Moultrie, J.; Young, A. Exploratory study of organizational creativity in creative organizations. Creat. Innov. Manag. 2009, 18, 299-314. [CrossRef]

48. Blauth, M.; Mauer, R.; Brettel, M. Fostering creativity in new product development through entrepreneurial decision making. Creat. Innov. Manag. 2014, 23, 495-509. [CrossRef]

49. Bharadwaj, S.; Menon, A. Making innovation happen in organizations: Individual creativity mechanisms, organizational creativity mechanisms, or both? J. Prod. Innov. Manag. Int. Publ. Prod. Dev. Manag. Assoc. 2000, 17, 424-434. [CrossRef]

50. Amabile, T.M.; Barsade, S.G.; Mueller, J.F.; Staw, B.M. Affect and creativity at work. Adm. Sci. Q. 2005, 50, 367-403. [CrossRef]

51. Im, S.; Workman, J.P., Jr. Market orientation, creativity, and new product performance in high-technology firms. J. Mark. 2004, 68, 114-132. [CrossRef]

52. Amabile, T.M. The social psychology of creativity: A componential conceptualization. J. Personal. Soc. Psychol. 1983, 45, 357. [CrossRef]

53. Lau, R.S.M. Competitive factors and their relative importance in the US electronics and computer industries. Int. J. Oper. Prod. Manag. 2002, 22, 125-135. [CrossRef]

54. Porter, M.E. Technology and competitive advantage. J. Bus. Strategy 1985, 5, 60. [CrossRef]

55. Rijamampianina, R.; Abratt, R.; February, Y. A framework for concentric diversification through sustainable competitive advantage. Manag. Decis. 2003, 41, 362-371. [CrossRef]

56. Li, T.; Calantone, R.J. The impact of market knowledge competence on new product advantage: Conceptualization and empirical examination. J. Mark. 1998, 62, 13-29. [CrossRef]

57. Carbonell, P.; Rodríguez-Escudero, A.I.; Pujari, D. Customer involvement in new service development: An examination of antecedents and outcomes. J. Prod. Innov. Manag. 2009, 26, 536-550. [CrossRef]

58. Joshi, A.W.; Sharma, S. Customer knowledge development: Antecedents and impact on new product performance. J. Mark. 2004, 68, 47-59. [CrossRef]

59. Fuchs, C.; Schreier, M. Customer empowerment in new product development. J. Prod. Innov. Manag. 2011, 28, 17-32. [CrossRef]

60. Yli-Renko, H.; Janakiraman, R. How customer portfolio affects new product development in technology-based entrepreneurial firms. J. Mark. 2008, 72, 131-148. [CrossRef]

61. Boso, N.; Cadogan, J.W.; Story, V.M. Entrepreneurial orientation and market orientation as drivers of product innovation success: A study of exporters from a developing economy. Int. Small Bus. J. 2013, 31, 57-81. [CrossRef]

62. Baker, W.E.; Sinkula, J.M. Does market orientation facilitate balanced innovation programs? An organizational learning perspective. J. Prod. Innov. Manag. 2007, 24, 316-334. [CrossRef]

63. Ma, Q.; Li, X.; Chaudhry, P.E.; Chaudhry, S.S. Public relations and legitimacy: A study of new ventures on the corporate life cycle. Syst. Res. Behav. Sci. 2020, 37, 699-710. [CrossRef]

64. Habib, A.; Hasan, M.M. Corporate life cycle research in accounting, finance, and corporate governance: A survey, and directions for future research. Int. Rev. Financ. Anal. 2019, 61, 188-201. [CrossRef]

65. Kim, J.K.; Kim, A. Corporate Life cycle and Restructuring. J. Digit. Converg. 2020, 18, 217-223.

66. Quinn, R.E.; Cameron, K. Organizational life cycles and shifting criteria of effectiveness: Some preliminary evidence. Manag. Sci. 1983, 29, 33-51. [CrossRef]

67. Miller, D.; Friesen, P.H. Porter's (1980) Generic strategies and performance: An empirical examination with American data: Part I: Testing Porter. Organ. Stud. 1986, 7, 37-55. [CrossRef]

68. Covin, J.G.; Miller, D. International entrepreneurial orientation: Conceptual considerations, research themes, measurement issues, and future research directions. Entrep. Theory Pract. 2014, 38, 11-44.

69. Lassen, A.H.; Gertsen, F.; Riss, J.O. The nexus of corporate entrepreneurship and radical innovation. Creat. Innov. Manag. 2006, 15, 359-372. [CrossRef]

70. Liu, S.S.; Luo, X.; Shi, Y.Z. Integrating customer orientation, corporate entrepreneurship, and learning orientation in organizationsin-transition: An empirical study. Int. J. Res. Mark. 2002, 19, 367-382. [CrossRef] 
71. Rickards, T.; Runco, M.A.; Moger, S. (Eds.) The Routledge Companion to Creativity; Routledge: London, UK, 2008.

72. Cooper, R.G.; Kleinschmidt, E.J. New products: What separates winners from losers? J. Prod. Innov. Manag. 1987, 4, 169-184. [CrossRef]

73. Song, X.M.; Parry, M.E. A cross-national comparative study of new product development processes: Japan and the United States. J. Mark. 1997, 61, 1-18. [CrossRef]

74. Homburg, C.; Workman, J.P., Jr.; Krohmer, H. Marketing's influence within the firm. J. Mark. 1999, 63, 1-17. [CrossRef]

75. Oliver, C. Sustainable competitive advantage: Combining institutional and resource-based views. Strateg. Manag. J. 1997, 18, 697-713. [CrossRef]

76. Anderson, E.W.; Fornell, C.; Lehmann, D.R. Customer satisfaction, market share, and profitability: Findings from Sweden. J. Mark. 1994, 58, 53-66. [CrossRef]

77. Zhang, Q.; Vonderembse, M.A.; Cao, M. Product concept and prototype flexibility in manufacturing: Implications for customer satisfaction. Eur. J. Oper. Res. 2009, 194, 143-154. [CrossRef]

78. Kleinschmidt, E.J.; Cooper, R.G. The impact of product innovativeness on performance. J. Prod. Innov. Manag. Int. Publ. Prod. Dev. Manag. Assoc. 1991, 8, 240-251. [CrossRef]

79. Song, M.; Montoya-Weiss, M.M. The effect of perceived technological uncertainty on Japanese new product development. Acad. Manag. J. 2001, 44, 61-80.

80. Hunt, S.D.; Morgan, R.M. The comparative advantage theory of competition. J. Mark. 1995, 59, 1-15. [CrossRef]

81. Hargadon, A.; Sutton, R.I. Technology brokering and innovation in a product development firm. Adm. Sci. Q. 1997, 42, 716-749. [CrossRef]

82. Ettlie, J.E.; Bridges, W.P.; O'keefe, R.D. Organization strategy and structural differences for radical versus incremental innovation. Manag. Sci. 1984, 30, 682-695. [CrossRef]

83. Langerak, F.; Hultink, E.J.; Robben, H.S. The impact of market orientation, product advantage, and launch proficiency on new product performance and organizational performance. J. Prod. Innov. Manag. 2004, 21, 79-94. [CrossRef]

84. Henard, D.H.; Szymanski, D.M. Why some new products are more successful than others? J. Mark. Res. 2001, 38, 362-375. [CrossRef]

85. Montoya-Weiss, M.M.; Calantone, R. Determinants of new product performance: A review and meta-analysis. J. Prod. Innov. Manag. Int. Publ. Prod. Dev. Manag. Assoc. 1994, 11, 397-417. [CrossRef]

86. Gupta, V.K.; Gupta, A. Relationship between entrepreneurial orientation and firm performance in large organizations over time. J. Int. Entrep. 2015, 13, 7-27. [CrossRef]

87. Griffin, A.; Page, A.L. An interim report on measuring product development success and failure. J. Prod. Innov. Manag. 1993, 10, 291-308. [CrossRef]

88. Covin, J.G.; Slevin, D.P. Strategic management of small firms in hostile and benign environments. Strateg. Manag. J. 1989, 10, 75-87. [CrossRef]

89. Hanks, S.H.; Watson, C.J.; Jansen, E.; Chandler, G.N. Tightening the lifecycle construct: A taxonomic study of growth stage configurations in high-technology organizations. Entrep. Theory Pract. 1994, 18, 5-29. [CrossRef]

90. Armstrong, J.S.; Overton, T.S. Estimating non-response bias in mail surveys. J. Mark. Res. 1977, 14, 396-402. [CrossRef]

91. Podsakoff, P.M.; Organ, D.W. Self-reports in organizational research: Problems and prospects. J. Manag. 1986, 12, 531-544. [CrossRef]

92. Nunnally, J.C.; Bernstein, I.H. Psychometric Theory, 3rd ed.; McGraw-Hill: New York, NY, USA, 1994.

93. Fornell, C.; Larcker, D.F. Evaluating structural equation models with unobservable variables and measurement error. J. Mark. Res. 1981, 18, 39-50. [CrossRef]

94. Bagozzi, R.P.; Yi, Y. On the evaluation of structural equation models. J. Acad. Mark. Sci. 1988, 16, 74-94. [CrossRef]

95. Bentler, P.M.; Dudgeon, P. Covariance structure analysis: Statistical practice, theory, and directions. Annu. Rev. Psychol. 1996, 47, 563-592. [CrossRef]

96. Arbuckle, J.L.; Wothke, W. Amos 4.0 User's Guide; Small Waters Corporation: Chicago, IL, USA, 1999.

97. Hair, J.F.; Black, W.C.; Babin, B.J.; Anderson, R.E.; Tatham, R. Multivariate Data Analysis; Pearson Prentice Hall: Upper Saddle River, NJ, USA, 2006.

98. Stone, E.F.; Hollenbeck, J.R. Clarifying some controversial issues surrounding statistical procedures for detecting moderator variables: Empirical evidence and related matters. J. Appl. Psychol. 1989, 74, 3. [CrossRef]

99. Lumpkin, G.T.; Dess, G.G. Linking two dimensions of entrepreneurial orientation to firm performance: The moderating role of environment and industry life cycle. J. Bus. Ventur. 2001, 16, 429-451. [CrossRef]

100. Rego, A.; Sousa, F.; Cunha, M.P.; Correia, A.; Amaral, I.S. Leader self-reported emotional intelligence and perceived employee creativity: An exploratory study. Creat. Innov. Manag. 2007, 16, 250-264. [CrossRef]

101. Akbar, F.; Khan, R.A.; Wadood, F.; Bon, A.T.B. Entrepreneurial orientation dimension affects firm performance: A perspective from the Malaysian furniture industry. Entrep. Bus. Econ. Rev. 2020, 8, 157-181.2.

102. Bhatti, A.; Rehman, S.U.; Rumman, J.B.A. Organizational capabilities mediates between organizational culture, entrepreneurial orientation, and organizational performance of SMEs in Pakistan. Entrep. Bus. Econ. Rev. 2020, 8, 85-103.

103. Stelmaszczyk, M. How Absorptive Capacity and Organisational Learning Orientation Interact to Enable Innovation Capability? An Empirical Examination. Entrep. Bus. Econ. Rev. 2020, 8, 7-32. [CrossRef] 